\title{
Loss on ignition: a qualitative or quantitative method for organic matter and carbonate mineral content in sediments?
}

Juan I. Santisteban ${ }^{1,2, *}$, Rosa Mediavilla ${ }^{3}$, Enrique López-Pamo ${ }^{4}$, Cristino J. Dabrio ${ }^{1}$, M. Blanca Ruiz Zapata ${ }^{2}$, M. José Gil García ${ }^{2}$, Silvino Castaño ${ }^{5}$ and Pedro E. MartínezAlfaro $^{6}$

${ }^{1}$ Department of Stratigraphy, Faculty of Geological Sciences, University Complutense of Madrid, C/ José Antonio Novais, 2, 28040-Madrid, Spain; ${ }^{2}$ Department of Geology, University of Alcalá, N-II, Km. 33,600, 28871 Alcalá de Henares, Madrid, Spain: ${ }^{3}$ Dirección de Geología y Geofísica, Instituto Geológico y Minero de España, c/ La Calera, 1, 28760 Tres Cantos, Madrid, Spain; ${ }^{4}$ Dirección de Recursos Minerales y Geoambiente, Instituto Geológico y Minero de España, c/ Ríos Rosas, 23, 28003 Madrid, Spain; ${ }^{5}$ Dirección de Hidrogeología y Aguas Subterráneas, Instituto Geológico y Minero de España, c/ Ríos Rosas, 23, 28003 Madrid, Spain; ${ }^{6}$ Department of Geodynamics, Faculty of Geological Sciences, University Complutense of Madrid, 28040 Madrid, Spain; *Author for correspondence (e-mail: juancho@geo.ucm.es)

Received 6 November 2003; accepted in revised form 1 March 2004

Key words: Carbonates, Clays, Evaporites, Lake sediments, Loss on ignition, Organic matter

\begin{abstract}
Since the publication of the paper of Dean (1974), loss on ignition (LOI) has been widely used as a method to estimate the amount of organic matter and carbonate mineral content (and indirectly of organic and inorganic carbon) in sediments. The relationships between LOI at $550{ }^{\circ} \mathrm{C}\left(\mathrm{LOI}_{550}\right)$ and organic carbon (OC) content and between LOI at $950{ }^{\circ} \mathrm{C}\left(\mathrm{LOI}_{950}\right)$ and inorganic carbon (IC) content are currently accepted as a standard. However, the comparison of 150 analyses of samples of diverse lithologies, collected from a single core, reveals that these relationships are affected by sediment composition (presence of clays, salts, and the variable content of organic carbon). This results in an incremental error on the estimation of carbon content from LOI values that invalidates the use of LOI values as a quantitative method for estimating carbon content. Conversely, the general trends of $\mathrm{LOI}_{550}$ and $\mathrm{LOI}_{950}$ show a good correlation with carbon content (both organic and inorganic) allowing use of LOI as a qualitative test for carbon content. Similarly, in our case, LOI at $105^{\circ} \mathrm{C}\left(\mathrm{LOI}_{105}\right)$ is a good qualitative proxy for the trends in gypsum content.
\end{abstract}

\section{Introduction}

Sequential loss on ignition (LOI) is a simple method for estimating the content of organic matter and carbonate minerals in sediments using the linear relations between LOI values and or- ganic and inorganic carbon content. Easy implementation in the laboratory makes the method widely used (e.g., Dean 1974, 1999; Korsman et al. 1999; Dodson and Ramrath 2001; Heiri et al. 2001; Boyle 2001, 2004; Bendell-Young et al. 2002; and Beaudoin 2003). 
The method is based on differential thermal analysis: organic matter begins to ignite at about $200{ }^{\circ} \mathrm{C}$ and is completely depleted at about $550{ }^{\circ} \mathrm{C}$, and most carbonate minerals are destroyed at higher temperatures (calcite between 800 and $850^{\circ} \mathrm{C}$, dolomite between 700 and $750{ }^{\circ} \mathrm{C}$ ). The organic carbon content has been experimentally calculated as about half the $\mathrm{LOI}_{550}$ (Dean 1974). Calculation of the inorganic carbon (IC) assumes that ignition follows a stoichiometric relationship (Dean 1974, 1999; Heiri et al. 2001), and that the amount of carbonate is $1.36 \times \mathrm{LOI}_{950}$ (Heiri et al. 2001). This implies that IC $=$ $0.273 \times \mathrm{LOI}_{950}$. Many authors (e.g., Meyers and Lallier-Verges 1999; Meyers and Teranes 2001) have remarked that certain volatile non-carbon components of the sediment increase the LOI values. One of the most influential is the lattice water in clays (Dean 1974; Ran et al. 2000; Heiri et al. 2001) that can account up to $5 \%$ in LOI. Gypsum, sulphide minerals, and metallic oxihydroxides can modify LOI values as well, via oxidation or dehydratation (Brauer et al. 2000; Rosen et al. 2002; Ralska-Jasiewiczowa et al. 2003). Additional errors come from loss of inorganic carbon at temperatures between 425 and $520^{\circ} \mathrm{C}$ in minerals such as siderite, magnesite, rhodochrosite and dolomite (Heiri et al. 2001). For this reason, Meyers and Lallier-Verges (1999) and Meyers and Teranes (2001) suggested other approximations for calculating carbon contents.

In spite of the previous considerations, many calculations of carbon contents in sediments found in the literature derive from $\mathrm{LOI}_{550}$ and $\mathrm{LOI}_{950}$ values. This is particularly important because fluctuations in carbon content are often correlated to climatic or biological changes, and have been widely used in the analysis of Plio-Quaternary deposits (e.g., Ramrath et al. 1999; Brauer et al. 2000; Valero-Garcés et al. 2000; Dodson and Ramrath 2001; Battarbee et al. 2002).

We intended to revise this idea when we began a study of wetland deposits in Las Tablas de Daimiel National Park in central Spain (Figure 1) in 2001. One of our main goals was to estimate the capacity of the environment to produce and store carbon. Available time and budget restrictions required a simple, cheap, reliable method to determine organic and carbonate contents. As a methodological approach, we sampled a core and compared the results obtained using LOI (following the method proposed by Heiri et al. 2001) and by direct measurement of organic and inorganic carbon in the same samples.

\section{Methods}

The $187 \mathrm{~cm}$-long core selected for high resolution sampling (Gigüela 4-2, Figure 1) includes diverse lithologies and variable contents of organic and inorganic carbon. Sampling spacing was $0.7 \mathrm{~cm}$ between 0 and $100 \mathrm{~cm}$, and $1.1 \mathrm{~cm}$ from $100 \mathrm{~cm}$ to the bottom, making a total of 213 samples. The upper 132 samples and one of each of three of the following samples (total: 162 samples) were se-

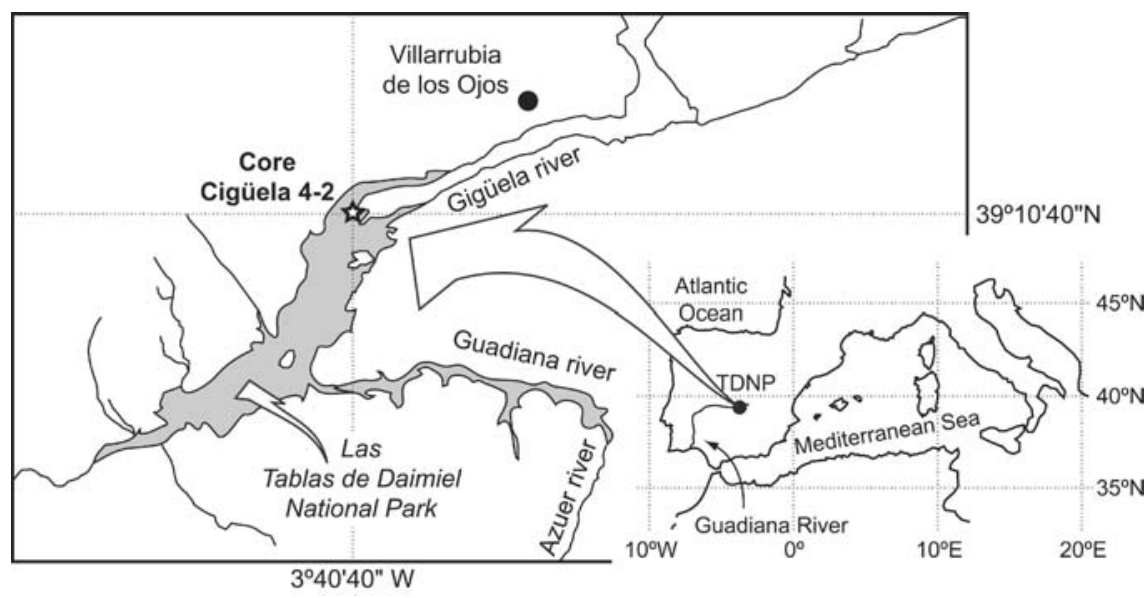

Figure 1. Location of core Gigüela 4-2. TDNP: Las Tablas de Daimiel National Park. 


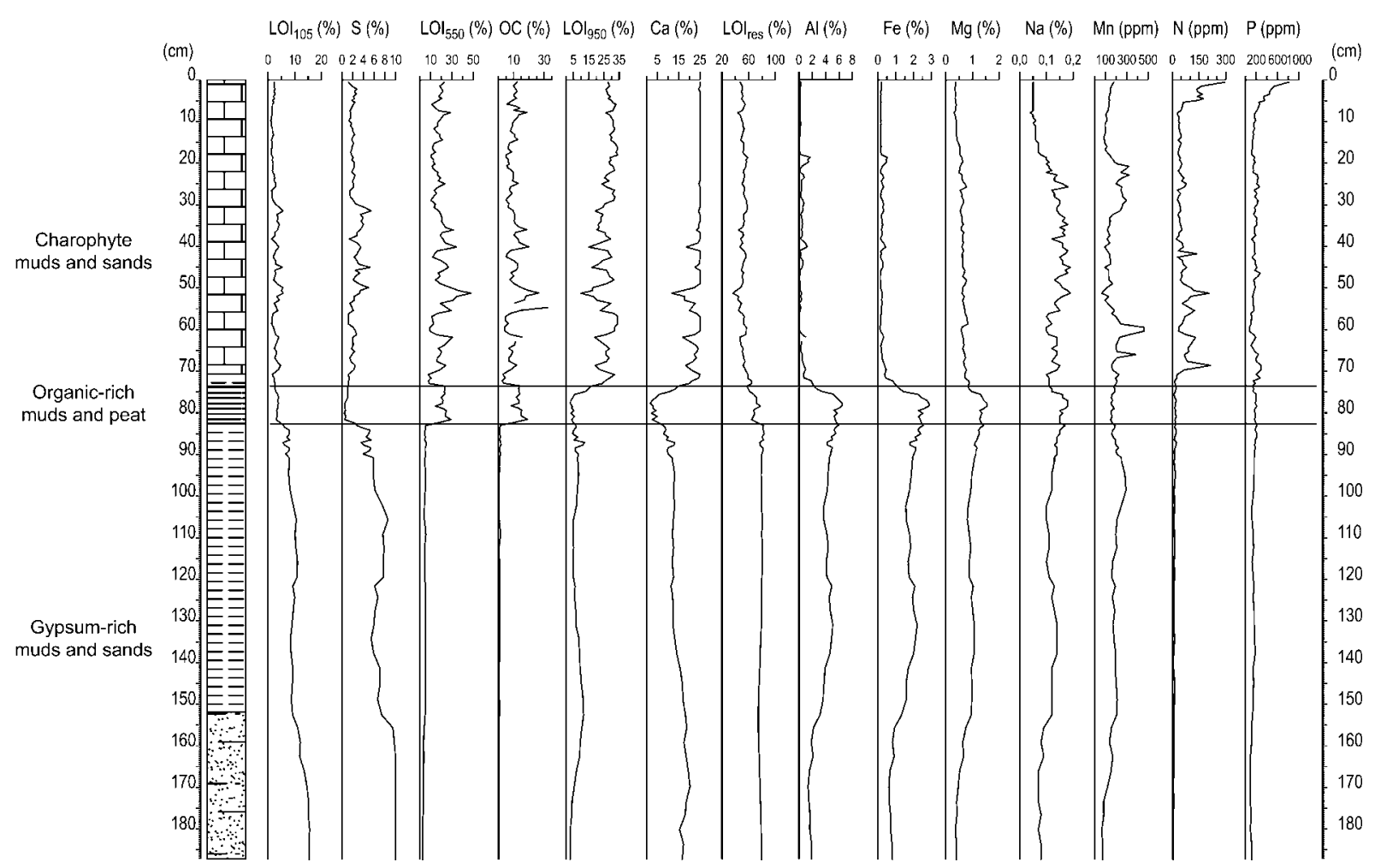

Figure 2. Stratigraphical log of core Gigüela 4-2 and main geochemical parameters analyzed in this paper.

Table 1. Statistical parameters of core Gigüela 4-2 $(n=150)$ (significance level of 0.05$)$

\begin{tabular}{lrrrrrrrrrrrllll}
\hline & LOI $_{105}$ & LOI $_{550}$ & LOI $_{950}$ & $\mathrm{LOI}_{\text {res }}$ & $\mathrm{IC}$ & $\mathrm{OC}$ & $\mathrm{Ca}$ & $\mathrm{S}$ & $\mathrm{Al}$ & $\mathrm{Fe}$ & $\mathrm{Mg}$ & $\mathrm{Na}$ & $\mathrm{Mn}$ & $\mathrm{P}$ & $\mathrm{N}$ \\
\hline Mean & 4.59 & 14.97 & 19.74 & 60.71 & 5.05 & 7.65 & 19.39 & 3.43 & 1.79 & 0.81 & 0.74 & 0.120 & 175 & 181 & 47.4 \\
Standard deviation & 3.64 & 8.54 & 10.68 & 12.61 & 2.74 & 5.49 & 6.93 & 2.54 & 2.03 & 0.85 & 0.30 & 0.040 & 67.38 & 87.29 & 46.49 \\
Variance & 13.26 & 72.87 & 114.05 & 159.10 & 7.48 & 30.13 & 47.98 & 6.47 & 4.11 & 0.72 & 0.09 & 0.002 & 4540.60 & 7620.03 & 2160.95 \\
Range & 14.58 & 45.33 & 31.27 & 46.65 & 8.69 & 26.15 & 23.22 & 9.58 & 6.39 & 2.75 & 1.23 & 0.15 & 396 & 740 & 290.2 \\
Minimum & 1.00 & 2.63 & 2.79 & 36.48 & 0.31 & 0.21 & 1.78 & 0.42 & 0.06 & 0.11 & 0.31 & 0.04 & 66 & 70 & 4.8 \\
Maximum & 15.57 & 47.96 & 34.06 & 83.13 & 9 & 26.36 & 25 & 10 & 6.45 & 2.86 & 1.54 & 0.19 & 462 & 810 & 295 \\
Confidence level (95\%) & 0.59 & 1.38 & 1.72 & 2.04 & 0.44 & 0.89 & 1.12 & 0.41 & 0.33 & 0.14 & 0.05 & 0.01 & 10.87 & 14.08 & 7.50 \\
\hline
\end{tabular}

Notice that 63 samples are above $25 \%$ of $\mathrm{Ca}$ and 10 samples are above $10 \%$ of S (detection limits). Units in \% except for Mn, $\mathrm{P}$ and $\mathrm{N}$ (in ppm).

lected for analysis by ALS Chemex Laboratories (Vancouver, Canada). Twelve samples did not weigh enough, so the total number of samples for carbon content measurement was reduced to 150 . All samples underwent double analyses: sequential loss on ignition and direct measurement of total carbon and inorganic carbon.

Sequential loss on ignition followed the method proposed by Heiri et al. (2001), with the modification by Bengtsson and Enell (1986) which takes into account the loss of mass at $105{ }^{\circ} \mathrm{C}$ and the residues after ignition for the calculation of the LOI. The process was:

(1) Dry the sample $12-24 \mathrm{~h}$ at $105^{\circ} \mathrm{C}$. Calculate the loss on ignition at $105^{\circ} \mathrm{C}\left(\mathrm{LOI}_{105}\right)$ as $\mathrm{LOI}_{105}=100\left(\mathrm{WS}-\mathrm{DW}_{105}\right) / \mathrm{WS}$, where WS is the weight of the air-dried sample and $\mathrm{DW}_{105}$ is the dry weight of the sample heated at $105{ }^{\circ} \mathrm{C}$. 
Table 2. Correlation coefficients for the whole core $(n=150)$ (significance level of 0.05 )

\begin{tabular}{|c|c|c|c|c|c|c|c|c|c|c|c|c|c|c|c|}
\hline & $\mathrm{LOI}_{105}$ & $\mathrm{LOI}_{550}$ & $\mathrm{LOI}_{950}$ & $\mathrm{LOI}_{\mathrm{res}}$ & IC & $\mathrm{OC}$ & $\mathrm{Ca}$ & $\mathrm{S}$ & $\mathrm{Al}$ & $\mathrm{Fe}$ & $\mathrm{Mg}$ & $\mathrm{Na}$ & $\mathrm{Mn}$ & $\mathrm{P}$ & $\mathrm{N}$ \\
\hline $\mathrm{LOI}_{105}$ & 1 & & & & & & & & & & & & & & \\
\hline $\mathrm{LOI}_{550}$ & -0.58 & 1 & & & & & & & & & & & & & \\
\hline $\mathrm{LOI}_{950}$ & -0.79 & 0.31 & 1 & & & & & & & & & & & & \\
\hline $\mathrm{LOI}_{\mathrm{res}}$ & 0.78 & -0.77 & -0.83 & 1 & & & & & & & & & & & \\
\hline IC & -0.77 & 0.32 & 0.99 & -0.84 & 1 & & & & & & & & & & \\
\hline $\mathrm{OC}$ & -0.61 & 0.99 & 0.32 & -0.76 & 0.31 & 1 & & & & & & & & & \\
\hline $\mathrm{Ca}$ & -0.48 & 0.17 & 0.89 & -0.73 & 0.90 & 0.15 & 1 & & & & & & & & \\
\hline $\mathrm{S}$ & 0.95 & -0.61 & -0.61 & 0.65 & -0.58 & -0.65 & -0.23 & 1 & & & & & & & \\
\hline $\mathrm{Al}$ & 0.49 & -0.39 & -0.86 & 0.85 & -0.88 & -0.37 & -0.94 & 0.29 & 1 & & & & & & \\
\hline $\mathrm{Fe}$ & 0.47 & -0.38 & -0.85 & 0.84 & -0.87 & -0.35 & -0.95 & 0.26 & 1.00 & 1 & & & & & \\
\hline $\mathrm{Mg}$ & 0.23 & -0.19 & -0.68 & 0.64 & -0.69 & -0.19 & -0.86 & 0.01 & 0.89 & 0.90 & 1 & & & & \\
\hline $\mathrm{Na}$ & -0.01 & 0.27 & -0.31 & 0.08 & -0.27 & 0.21 & -0.37 & -0.10 & 0.32 & 0.32 & 0.61 & 1 & & & \\
\hline $\mathrm{Mn}$ & -0.10 & -0.27 & 0.08 & 0.14 & 0.08 & -0.29 & 0.00 & -0.09 & 0.10 & 0.10 & 0.21 & 0.17 & 1 & & \\
\hline $\mathrm{P}$ & -0.28 & 0.24 & 0.19 & -0.24 & 0.16 & 0.23 & 0.15 & -0.29 & -0.13 & -0.12 & -0.15 & -0.15 & -0.04 & 1 & \\
\hline $\mathrm{N}$ & -0.39 & 0.57 & 0.42 & -0.63 & 0.42 & 0.50 & 0.39 & -0.35 & -0.51 & -0.50 & -0.43 & -0.10 & -0.11 & 0.67 & 1 \\
\hline
\end{tabular}

Sixty three samples above $25 \%$ of $\mathrm{Ca}$ and 10 samples above $10 \%$ of $\mathrm{S}$ (detection limits).

Table 3. Correlation coefficients for the green gypsum-rich muds and sands $(n=41)$ (significance level of 0.05 )

\begin{tabular}{|c|c|c|c|c|c|c|c|c|c|c|c|c|c|c|c|}
\hline & $\mathrm{LOI}_{105}$ & $\mathrm{LOI}_{550}$ & $\mathrm{LOI}_{950}$ & $\mathrm{LOI}_{\mathrm{res}}$ & IC & $\mathrm{OC}$ & $\mathrm{Ca}$ & $\mathrm{S}$ & $\mathrm{Al}$ & $\mathrm{Fe}$ & $\mathrm{Mg}$ & $\mathrm{Na}$ & $\mathrm{Mn}$ & $\mathrm{P}$ & $\mathrm{N}$ \\
\hline $\mathrm{LOI}_{105}$ & 1 & & & & & & & & & & & & & & \\
\hline $\mathrm{LOI}_{550}$ & -0.92 & 1 & & & & & & & & & & & & & \\
\hline $\mathrm{LOI}_{950}$ & -0.54 & 0.52 & 1 & & & & & & & & & & & & \\
\hline $\mathrm{LOI}_{\mathrm{res}}$ & -0.30 & 0.18 & -0.64 & 1 & & & & & & & & & & & \\
\hline IC & -0.34 & 0.39 & 0.96 & -0.79 & 1 & & & & & & & & & & \\
\hline $\mathrm{OC}$ & -0.79 & 0.77 & 0.29 & 0.36 & 0.07 & 1 & & & & & & & & & \\
\hline $\mathrm{Ca}$ & 0.73 & -0.63 & 0.17 & -0.85 & 0.38 & -0.68 & 1 & & & & & & & & \\
\hline $\mathrm{S}$ & 0.94 & -0.87 & -0.34 & -0.46 & -0.13 & -0.82 & 0.82 & 1 & & & & & & & \\
\hline Al & -0.88 & 0.84 & 0.13 & 0.62 & -0.05 & 0.67 & -0.91 & -0.90 & 1 & & & & & & \\
\hline $\mathrm{Fe}$ & -0.88 & 0.84 & 0.13 & 0.62 & -0.04 & 0.67 & -0.91 & -0.91 & 1.00 & 1 & & & & & \\
\hline $\mathrm{Mg}$ & -0.96 & 0.88 & 0.35 & 0.46 & 0.16 & 0.74 & -0.82 & -0.94 & 0.95 & 0.95 & 1 & & & & \\
\hline $\mathrm{Na}$ & -0.92 & 0.84 & 0.29 & 0.49 & 0.10 & 0.73 & -0.82 & -0.96 & 0.95 & 0.95 & 0.97 & 1 & & & \\
\hline $\mathrm{Mn}$ & -0.77 & 0.72 & 0.50 & 0.12 & 0.39 & 0.42 & -0.45 & -0.59 & 0.63 & 0.62 & 0.67 & 0.57 & 1 & & \\
\hline $\mathrm{P}$ & -0.87 & 0.78 & 0.21 & 0.55 & 0.01 & 0.75 & -0.84 & -0.94 & 0.92 & 0.92 & 0.93 & 0.96 & 0.50 & 1 & \\
\hline $\mathrm{N}$ & -0.68 & 0.57 & 0.27 & 0.32 & 0.09 & 0.65 & -0.57 & -0.68 & 0.57 & 0.57 & 0.64 & 0.59 & 0.41 & 0.65 & 1 \\
\hline
\end{tabular}

Ten samples above $10 \%$ of $\mathrm{S}$ (detection limit).

(2) Burn the sample at $550{ }^{\circ} \mathrm{C}$ for $4 \mathrm{~h}$. Calculate $\mathrm{LOI}_{550}=100\left(\mathrm{DW}_{105}-\mathrm{DW}_{550}\right) / \mathrm{WS}$, where $\mathrm{LOI}_{550}$ is the percentage of loss on ignition at $550{ }^{\circ} \mathrm{C}$ and $\mathrm{DW}_{550}$ is the weight of the sample after heating at $550{ }^{\circ} \mathrm{C}$.

(3) Heat the sample at $950{ }^{\circ} \mathrm{C}$ for $2 \mathrm{~h}$; calculate $\mathrm{LOI}_{950}=100\left(\mathrm{DW}_{550}-\mathrm{DW}_{950}\right) / \mathrm{WS}$, where $\mathrm{LOI}_{950}$ is the percentage of loss on ignition at $950{ }^{\circ} \mathrm{C}$ and $\mathrm{DW}_{950}$ is the weight of the sample after heating at $950{ }^{\circ} \mathrm{C}$. The remaining sample, after heating at $950{ }^{\circ} \mathrm{C}$, is the residuum ( $\mathrm{LOI}_{\mathrm{res}}$ ).
Direct measurement of total carbon content was achieved with a Leco $^{\odot}$ SC-444DR carbon and sulphur analyser. Inorganic carbon (IC) was measured by $\mathrm{CO}_{2}$ coulometry with an $\mathrm{UIC}^{\odot}$ CM140 Total Inorganic Carbon Analyser. The content in organic carbon (OC) is the difference between the previous values.

It was also important to know the influence of other minerals in LOI values. Mineralogy was determined by X-ray diffractometry (XRD) at the Department of Geology of the University of Salamanca (Spain), using a Siemens D-500 XRD 
Table 4. Correlation coefficients for the organic-rich muds and peat $(n=14)$ (significance level of 0.05$)$

\begin{tabular}{|c|c|c|c|c|c|c|c|c|c|c|c|c|c|c|c|}
\hline & $\mathrm{LOI}_{105}$ & $\mathrm{LOI}_{550}$ & $\mathrm{LOI}_{950}$ & $\mathrm{LOI}_{\mathrm{res}}$ & IC & $\mathrm{OC}$ & $\mathrm{Ca}$ & $\mathrm{S}$ & $\mathrm{Al}$ & $\mathrm{Fe}$ & $\mathrm{Mg}$ & $\mathrm{Na}$ & $\mathrm{Mn}$ & $\mathrm{P}$ & $\mathrm{N}$ \\
\hline $\mathrm{LOI}_{105}$ & 1 & & & & & & & & & & & & & & \\
\hline $\mathrm{LOI}_{550}$ & -0.61 & 1 & & & & & & & & & & & & & \\
\hline $\mathrm{LOI}_{950}$ & -0.74 & 0.16 & 1 & & & & & & & & & & & & \\
\hline $\mathrm{LOI}_{\mathrm{res}}$ & 0.87 & -0.69 & -0.82 & 1 & & & & & & & & & & & \\
\hline $\mathrm{IC}$ & -0.76 & 0.19 & 1.00 & -0.84 & 1 & & & & & & & & & & \\
\hline $\mathrm{OC}$ & -0.50 & 0.98 & 0.01 & -0.57 & 0.04 & 1 & & & & & & & & & \\
\hline $\mathrm{Ca}$ & -0.66 & 0.11 & 0.99 & -0.79 & 0.99 & -0.04 & 1 & & & & & & & & \\
\hline S & 0.37 & -0.43 & 0.28 & 0.00 & 0.27 & -0.47 & 0.40 & 1 & & & & & & & \\
\hline $\mathrm{Al}$ & 0.77 & -0.32 & -0.98 & 0.90 & -0.98 & -0.17 & -0.97 & -0.27 & 1 & & & & & & \\
\hline $\mathrm{Fe}$ & 0.77 & -0.33 & -0.97 & 0.91 & -0.98 & -0.18 & -0.97 & -0.27 & 1.00 & 1 & & & & & \\
\hline $\mathrm{Mg}$ & 0.77 & -0.38 & -0.96 & 0.92 & -0.96 & -0.23 & -0.95 & -0.28 & 0.99 & 0.99 & 1 & & & & \\
\hline $\mathrm{Na}$ & 0.70 & -0.37 & -0.91 & 0.88 & -0.92 & -0.23 & -0.91 & -0.34 & 0.95 & 0.97 & 0.97 & 1 & & & \\
\hline $\mathrm{Mn}$ & -0.46 & -0.13 & 0.72 & -0.45 & 0.72 & -0.27 & 0.71 & 0.22 & -0.65 & -0.65 & -0.61 & -0.54 & 1 & & \\
\hline $\mathrm{P}$ & 0.80 & -0.52 & -0.80 & 0.88 & -0.80 & -0.42 & -0.75 & -0.01 & 0.84 & 0.85 & 0.85 & 0.85 & -0.50 & 1 & \\
\hline $\mathrm{N}$ & -0.33 & 0.07 & 0.32 & -0.27 & 0.33 & 0.04 & 0.28 & -0.01 & -0.30 & -0.28 & -0.31 & -0.27 & 0.26 & -0.41 & 1 \\
\hline
\end{tabular}

Table 5. Correlation coefficients for the Charophyte-rich layers with vegetal lamina $(n=95)$ (significance level of 0.05$)$

\begin{tabular}{|c|c|c|c|c|c|c|c|c|c|c|c|c|c|c|c|}
\hline & $\mathrm{LOI}_{105}$ & $\mathrm{LOI}_{550}$ & $\mathrm{LOI}_{950}$ & $\mathrm{LOI}_{\mathrm{res}}$ & IC & $\mathrm{OC}$ & $\mathrm{Ca}$ & $\mathrm{S}$ & $\mathrm{Al}$ & $\mathrm{Fe}$ & $\mathrm{Mg}$ & $\mathrm{Na}$ & $\mathrm{Mn}$ & $\mathrm{P}$ & $\mathrm{N}$ \\
\hline $\mathrm{LOI}_{105}$ & 1 & & & & & & & & & & & & & & \\
\hline $\mathrm{LOI}_{550}$ & 0.64 & 1 & & & & & & & & & & & & & \\
\hline $\mathrm{LOI}_{950}$ & -0.90 & -0.81 & 1 & & & & & & & & & & & & \\
\hline $\mathrm{LOI}_{\text {res }}$ & -0.27 & -0.87 & 0.42 & 1 & & & & & & & & & & & \\
\hline IC & -0.83 & -0.81 & 0.94 & 0.46 & 1 & & & & & & & & & & \\
\hline OC & 0.51 & 0.97 & -0.72 & -0.89 & -0.76 & 1 & & & & & & & & & \\
\hline $\mathrm{Ca}$ & -0.63 & -0.67 & 0.72 & 0.43 & 0.68 & -0.57 & 1 & & & & & & & & \\
\hline S & 0.78 & 0.40 & -0.65 & -0.12 & -0.63 & 0.35 & -0.15 & 1 & & & & & & & \\
\hline $\mathrm{Al}$ & 0.19 & -0.10 & -0.33 & 0.49 & -0.27 & -0.16 & -0.27 & 0.04 & 1 & & & & & & \\
\hline $\mathrm{Fe}$ & 0.18 & -0.16 & -0.29 & 0.53 & -0.22 & -0.22 & -0.31 & -0.04 & 0.94 & 1 & & & & & \\
\hline $\mathrm{Mg}$ & 0.35 & -0.03 & -0.27 & 0.27 & -0.11 & -0.17 & -0.32 & 0.07 & 0.42 & 0.46 & 1 & & & & \\
\hline $\mathrm{Na}$ & 0.66 & 0.36 & -0.61 & -0.06 & -0.49 & 0.23 & -0.37 & 0.54 & 0.23 & 0.17 & 0.76 & 1 & & & \\
\hline $\mathrm{Mn}$ & -0.07 & -0.42 & 0.20 & 0.47 & 0.23 & -0.47 & 0.14 & -0.12 & 0.15 & 0.13 & 0.30 & 0.13 & 1 & & \\
\hline $\mathrm{P}$ & 0.06 & 0.10 & -0.08 & -0.09 & -0.16 & 0.10 & 0.09 & -0.01 & -0.01 & 0.01 & -0.36 & -0.27 & -0.08 & 1 & \\
\hline $\mathrm{N}$ & 0.36 & 0.47 & -0.36 & -0.45 & -0.41 & 0.41 & -0.40 & 0.07 & -0.13 & -0.12 & -0.18 & -0.06 & -0.14 & 0.68 & 1 \\
\hline
\end{tabular}

Sixty three samples above $25 \%$ of $\mathrm{Ca}$ (detection limit).

diffractometer with a $\mathrm{Cu}$ anticathode and a graphite monochromator. In addition, the procedure to determine $\mathrm{P}, \mathrm{Al}, \mathrm{Ca}, \mathrm{S}, \mathrm{Na}, \mathrm{Mn}$ and $\mathrm{Fe}$ was $\mathrm{HF}-\mathrm{HNO}_{3}-\mathrm{HClO}_{4}$ acid digestion, $\mathrm{HCl}$ leach and a combination of ICP-MS and ICP-AES. Nitrogen was determined as extractable $\mathrm{N}\left(\mathrm{NH}_{4}\right.$, using a Technicon Autoanalyser ${ }^{\odot}$, and $\mathrm{NO}_{3}$, colorimetrically using the CTA method) at ALS Chemex Labs.

We used the $\mathrm{R}$ system (Ihaka and Gentleman 1996) to perform cross-correlation and principal components analysis (Lebreton et al. 1991; Boyle 2001; Grunsky 2001) for Al, Ca, S, Na, Mn, Fe,
$\mathrm{LOI}_{105}, \mathrm{LOI}_{550}, \mathrm{LOI}_{950}, \mathrm{LOI}_{\text {res }}, \mathrm{IC}, \mathrm{OC}, \mathrm{N}$ and $\mathrm{P}$, both for the whole core and for each facies. We performed linear regression of the LOI data for the total core data and for each separate facies.

$\mathrm{LOI}_{550}$ and $\mathrm{LOI}_{950}$ results were used to determine organic (OC) and inorganic (IC) carbon contents by means of Dean's $(1974,1999)$ relations $\left(\mathrm{OC}=\mathrm{LOI}_{550} / 2, \mathrm{IC}=0.273 \mathrm{LOI}_{950}\right)$, and our regression equations for the whole core data. Both sets of values were compared with direct measurements of $\mathrm{C}$ to determine the benefit achieved by generating a new set of equations prior to LOI analyses. 

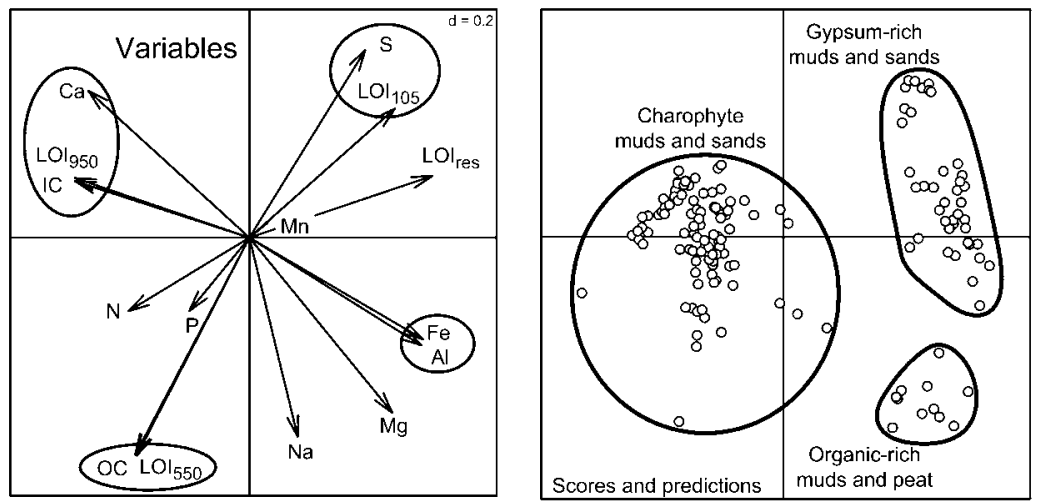

Gypsum-rich muds and sands

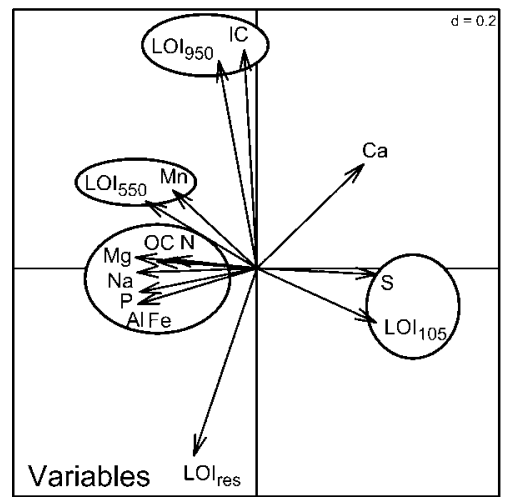

Organic-rich muds and peat

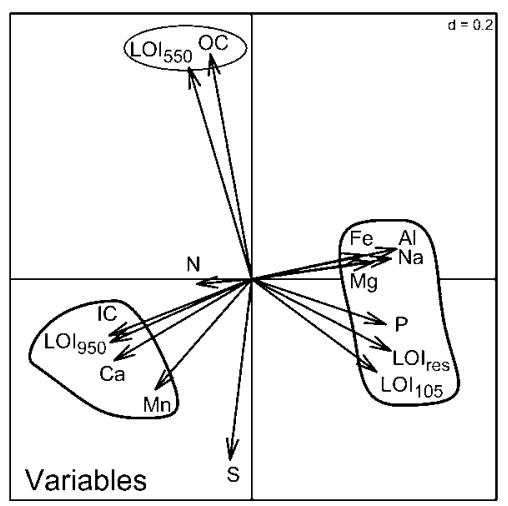

Charophyte muds and sands

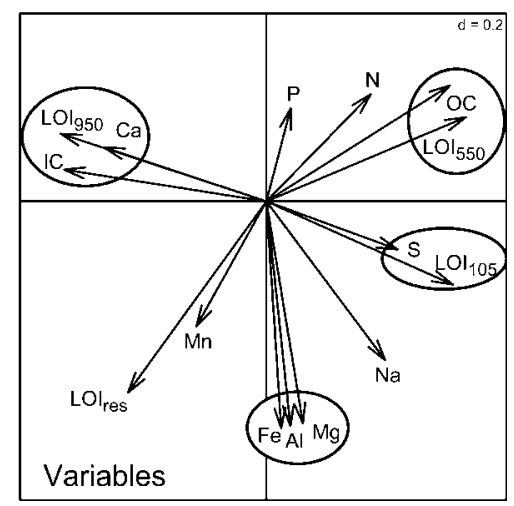

Variables

Figure 3. Principal components analyses. Variable relationships and scores and predictions.

\section{Analyzed materials}

The core Gigüela 4-2, Holocene in age, consists of three main facies (Figure 2): (i) Gypsum-rich siliciclastic mud and sand, (ii) organic mud and peat, and (iii) charophyte mud to sand layers with vegetal organic matter. The mineralogy of these materials is calcite $(0-99 \%)$, quartz $(0-17 \%)$, phyllosilicates $(0-81 \%)$, gypsum $(0-55 \%)$ and, as a minor component, feldspar $(0-5 \%)$ in some samples. As a whole, the content of organic and inorganic carbon varies widely, as do $\mathrm{Ca}, \mathrm{S}, \mathrm{Al}$, $\mathrm{Mn}, \mathrm{N}$ and $\mathrm{P}$. In contrast, $\mathrm{Mg}, \mathrm{Na}$ and Fe fluctuate less (Table 1).

\section{Discussion}

\section{Geochemical and mineralogical relationships}

Correlation and principal components analyses, using LOI values and the main geochemical indi- cators of the mineralogy, were used to confirm the dependence of LOI values on lithology. The analyses were performed for the whole core (Table 2) and for each facies (Tables 3-5) and the results are presented as principal components graphs that show the main relations among parameters (Figure 3).

Regarding the whole core, principal components analysis reveals two main factors that explain most of the sediment composition.

Factor 1 comprises IC-Ca-LOI 950 , which represents the carbonate mineral content of the sediment, as opposed to $\mathrm{Al}-\mathrm{Fe}$ which characterize the clay content. Factor 2 contains $\mathrm{OC}-\mathrm{LOI}_{550}$, corresponding to the organic content of the sediment, as opposed to $\mathrm{S}-\mathrm{LOI}_{105}$ which stands for the gypsum content.

However, analysing samples as lithology groups reveals a rather different picture. For the gypsumrich siliciclastic mud and sand, the most significant factor shows $\mathrm{Al}-\mathrm{Fe}$ and $\mathrm{OC}-\mathrm{LOI}_{550}$ (including $\mathrm{Mg}, \mathrm{Na}$ and $\mathrm{P}$ ) as opposed to $\mathrm{S}-\mathrm{LOI}_{105}$ (Figure 3, 

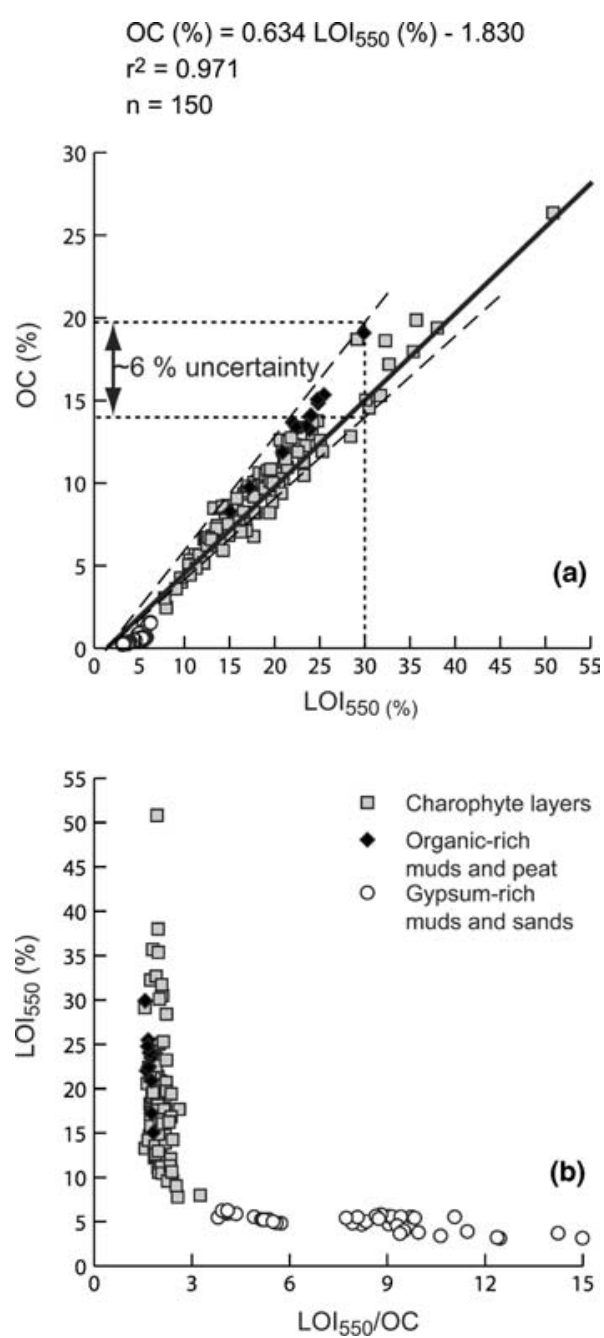

Figure 4. Correlation graphs between (a) $\mathrm{LOI}_{550}$ and organic carbon content, and (b) the variability of the $\mathrm{LOI}_{550} / \mathrm{OC}$ ratios in relation to LOI values. Correlation equations are derived for the whole number of samples.

Table 3) and $\mathrm{IC}-\mathrm{LOI}_{950}$ versus $\mathrm{LOI}_{\text {res }}$ as a second factor. A main difference in the results of the whole core is the shift of $\mathrm{Ca}$ towards $\mathrm{S}-\mathrm{LOI}_{105}$ (correlation coefficient $\mathrm{S}-\mathrm{Ca}=0.82$, significance level of 0.05 ) due to the high content of gypsum.

There is a major change in relations for the organic-rich mud and peat (Figure 3, Table 4). The main factor encloses $\mathrm{Al}-\mathrm{Fe}$ as opposed to $\mathrm{IC}-\mathrm{Ca}-$ $\mathrm{LOI}_{950}$. Factor 2 is represented by $\mathrm{OC}-\mathrm{LOI}_{550}$ versus $\mathrm{S}$, which has very little weight, but these show moderate to low correlation coefficients with the other components. The pair $\mathrm{Al}-\mathrm{Fe}$ is also correlated to $\mathrm{LOI}_{\text {res }}$ and $\mathrm{LOI}_{105}$.
For the charophyte mud to sand layers with vegetal organic matter, the main factor shows IC$\mathrm{Ca}-\mathrm{LOI}_{950}$ with lower weighting on $\mathrm{OC}-\mathrm{LOI}_{550}$ and $\mathrm{S}-\mathrm{LOI}_{105}$; factor 2 is composed of $\mathrm{Al}-\mathrm{Fe}$ by as opposed to $\mathrm{LOI}_{\text {res }}$ (Figure 3, Table 5). Al-Fe has very low correlation coefficients $(-0.33$ to 0.53 , significance level of 0.05 ) with the other components reflecting the very low content in clay of this facies.

In summary, the parameters analysed can be grouped as: (1) $\mathrm{Al}-\mathrm{Fe}$ group (with occasional influence of $\mathrm{Na}, \mathrm{Mg}$ and $\mathrm{P}$ ), which represent the clay content, (2) OC- $\mathrm{LOI}_{550}$ group (with $\mathrm{N}$ and $\mathrm{P}$ as minor constituents) representing the organic matter content, (3) IC-Ca- $\mathrm{LOI}_{950}$ group representing the calcite content and (4) S- $-\mathrm{LI}_{105}$ group related to the gypsum content. Other parameters such as $\mathrm{Mn}, \mathrm{Mg}, \mathrm{Na}, \mathrm{P}, \mathrm{N}$ and $\mathrm{LOI}_{\text {res }}$ play a minor role and shift from one group to other depending on the mineralogy of the facies.

\section{Carbon versus LOI record}

A first test of the reliability of LOI data for the estimation of carbon content is direct (visual) comparison of the results obtained using LOI with direct measurements of carbon (Figure 2). As values and trends are very similar, regression analyses were performed for organic carbon (OC) versus $\mathrm{LOI}_{550}$ (Figure 4, Table 6) and for inorganic carbon (IC) versus $\mathrm{LOI}_{950}$ (Figure 5, Table 7).

There is very good numerical correlation of $\mathrm{LOI}_{550}$ with OC except for the gypsum-rich facies (Table 6, Figure 4a). $\mathrm{LOI}_{550} / \mathrm{OC}$ ratio follows the expected behaviour: the ratio is almost constant for $\mathrm{LOI}_{550}$ values higher than $5 \%$ and there is no obvious relation for lower values (Figure 4b), which is interpreted to be a result of the low content in organic carbon in this facies.

More detailed analysis of this relationship reveals that as $\mathrm{LOI}_{550}$ values increase, the range of observed OC values widens introducing an incremental uncertainty to the $\mathrm{OC}$ estimations derived from $\mathrm{LOI}_{550}$. For instance, OC content ranges between 13.98 and $19.74 \%$ (range: $5.76 \%$ ) when $\mathrm{LOI}_{550}$ reaches $30 \%$ (Figure $4 \mathrm{a}$ ) and between 18.89 and $26.6 \%$ (range: $7.7 \%$ ) for a $\mathrm{LOI}_{550}$ value of $40 \%$.

Regression data for IC versus $\mathrm{LOI}_{950}$ are better for all the data sets (Table 7, Figure 5a), but the 
Table 6. Regression coefficients $\left(\mathrm{OC}=a * \mathrm{LOI}_{550}+b\right)$ for organic carbon (OC) (significance level of 0.05 )

\begin{tabular}{lll}
\hline & Equation & $r^{2}$ \\
\hline Whole core & $a=0.634, b=-1.830$ & 0.971 \\
Charophyte layers & $a=0.579, b=-0.889$ & 0.948 \\
Organic-rich muds & $a=0.707, b=-2.100$ & 0.963 \\
Gypsum-rich muds & $a=0.332, b=-0.760$ & 0.593 \\
\hline
\end{tabular}

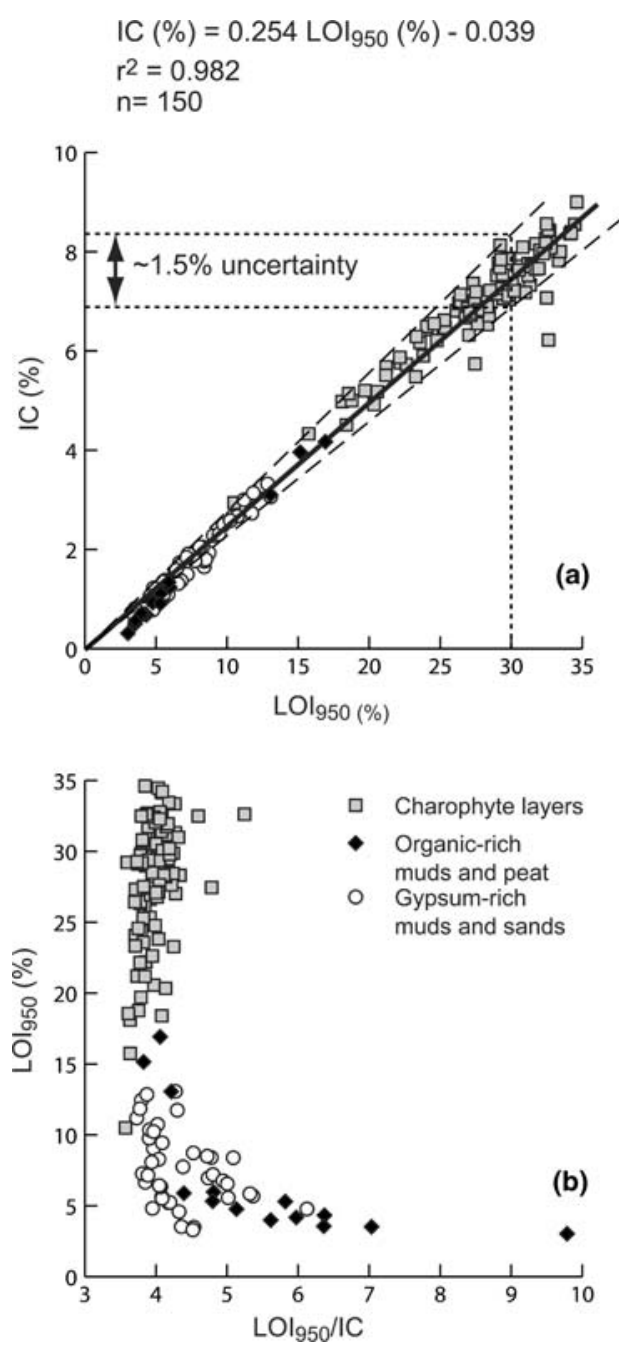

Figure 5. Correlation graphs between (a) $\mathrm{LOI}_{950}$ and inorganic carbon content, and (b) the variability of the $\mathrm{LOI}_{950} / \mathrm{IC}$ ratios in relation to LOI values. Correlation equations are derived for the whole number of samples.

range of values for the $\mathrm{LOI}_{950} / \mathrm{IC}$ ratio is wider than for the $\mathrm{LOI}_{550} / \mathrm{OC}$ ratio, particularly for samples of the organic-rich mud, carbonate-poor, facies (Figure $5 b$ ). As for $\mathrm{LOI}_{550}$, the sample data reveal a broad range of observed IC values for a single $\mathrm{LOI}_{950}$ value, which means an increasing error in IC estimation as the $\mathrm{LOI}_{950}$ value increases. For instance, the observed IC content varies from 6.8 to $8.4 \%$ for a $\mathrm{LOI}_{950}$ of $30 \%$ (Figure 5a).

\section{Comparison with established relations}

In order to check the accuracy of the LOI technique, the carbon content was calculated using Dean's $(1974,1999)$ relations and our own regression equations (Tables 6 and 7). These values (value $_{\text {sim }}$ in Figure 6), were compared to the carbon content obtained by direct measurement (value $_{\text {obs }}$ in Figure 6) and a percentage of variation was obtained as $\left[100 *\left(\right.\right.$ value $_{\text {obs }}-$ value $\left._{\text {sim }}\right) /$ value $\left._{\text {obs }}\right]$. The range of this percentage of variation is very wide (Figure 6, Table 8), reflecting the clear dependence on lithology and the regression model selected.

Regarding the OC, Dean's (1974) relation systematically overestimates the OC content, with the maximum variation (almost 560\%) found in the gypsum-rich, organic-poor, facies (Figure 6). In contrast, using our equations the variations fluctuate around the $0 \%$ line. The IC estimation yields better results, as the variation for the both approaches decrease to about $165 \%$.

The nearly constant variation of data for OC and IC does not extend to the organic-rich mud facies, where variations experience a major shift (Figure 6). This shift is striking because the IC content of the two mud facies (organic or gypsumrich) are similar.

Normalized $\mathrm{LOI}_{550}, \mathrm{OC}, \mathrm{LOI}_{950}$ and IC data for the whole core and for every facies (Figure 7) show good agreement of trends despite the shifts of absolute values. However, closer inspection of the OC- $\mathrm{LOI}_{550}$ diagram reveals that some observed peaks of $\mathrm{OC}$ are masked on the $\mathrm{LOI}_{550}$ curve (Figure 7).

$\mathrm{LOI}_{105}$ and $\mathrm{LOI}_{\text {res }}$

As expected, the sedimentary facies share strong correlations between (i) $\mathrm{LOI}_{550}$ and $\mathrm{OC}$ and (ii) $\mathrm{LOI}_{950}$ and IC. However, the behaviour of $\mathrm{LOI}_{105}$ and $\mathrm{LOI}_{\text {res }}$ vary depending on the lithology. 


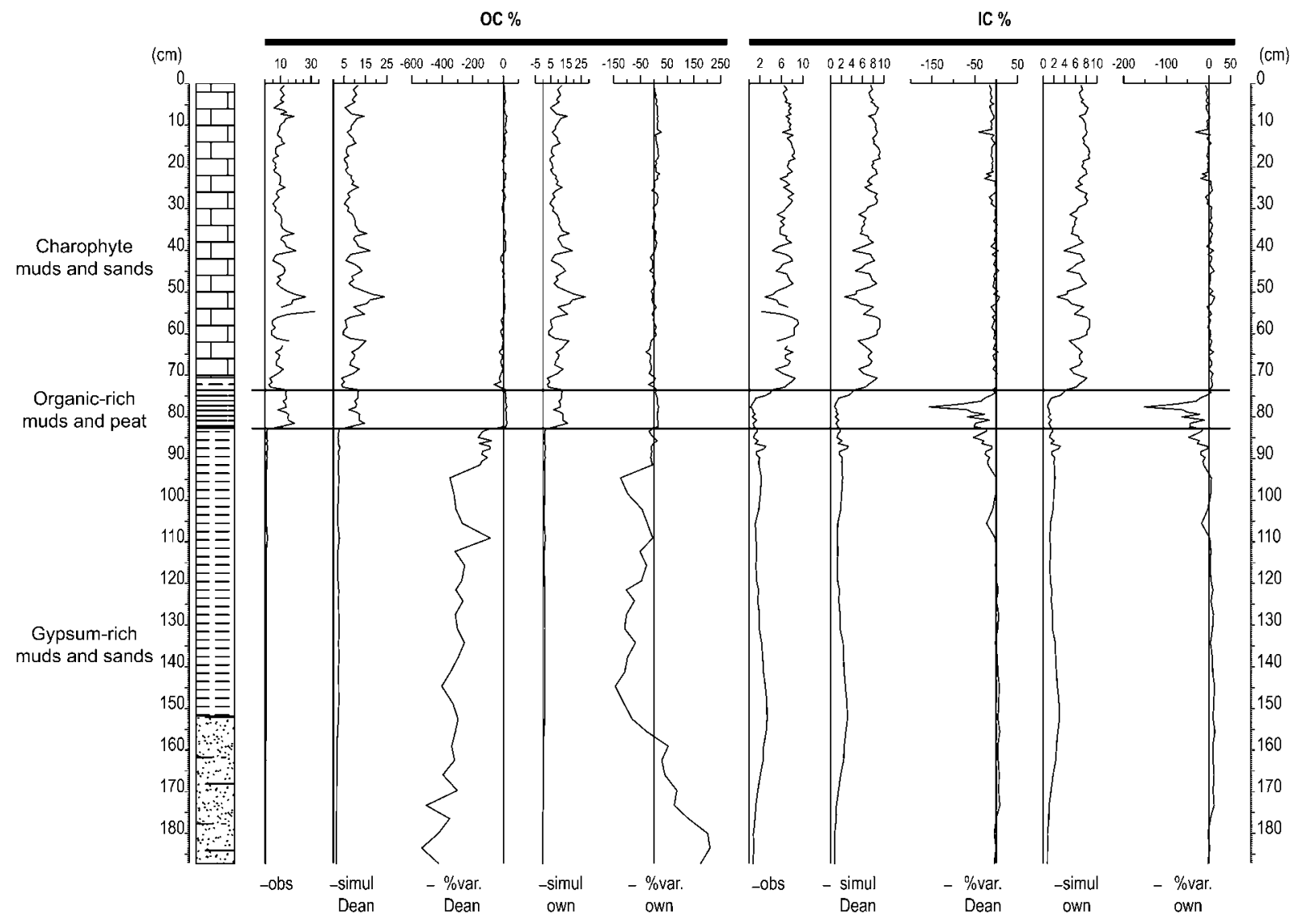

Figure 6. Comparison between observed (obs.) and simulated (sim.) carbon values and the percentage of variation between them.

Table 7. Regression coefficients (IC $=a * \mathrm{LOI}_{950}+b$ ) for inorganic carbon (IC) (significance level of 0.05)

\begin{tabular}{lll}
\hline & Equation & $r^{2}$ \\
\hline Whole core & $a=0.254, b=-0.039$ & 0.982 \\
Charophyte layers & $a=0.215, b=1.137$ & 0.879 \\
Organic-rich muds & $a=0.286, b=-0.436$ & 0.995 \\
Gypsum-rich muds & $a=0.286, b=-0.170$ & 0.924 \\
\hline
\end{tabular}

$\mathrm{LOI}_{105}$ is usually related to $\mathrm{S}$ except in the organicrich mud and peat layers. $\mathrm{LOI}_{\text {res }}$ is related to the Al-Fe group in the organic-rich mud and peat, but it does not show clear relations with the other facies (Figure 3).

A major point is that $\mathrm{LOI}_{105}$ is related to water loss and, therefore, reflects the dewatering of organic matter and water-bearing minerals (in our case clay and gypsum) in addition to loss of pore waters. Thus, $\mathrm{LOI}_{105}$ values depend in part on the amount of such components, but it is important to remember that clays lose water over a wide range of temperatures, that surpasses $950{ }^{\circ} \mathrm{C}$ (Brindley and Le Maitre 1987). Thus, at least in theory, $\mathrm{LOI}_{105}$ only provides an estimate on the loss of water (pore, "organic", and lattice waters of clays and salts).

In our case, it is clear that $\mathrm{LOI}_{105}$ and $\mathrm{S}$ follow similar trends (Figure 2) and regression analysis reveals a good fit $\left(r^{2}=0.839\right)$ for the whole core data (Table 9). However, $r^{2}$ is extremely variable for each facies (charophyte layers: $r^{2}=0.615$; organic-rich mud: $r^{2}=0.139$; gypsum-rich mud and sand: $r^{2}=0.912$ ). Regression of $\mathrm{LOI}_{105}$ on $\mathrm{Al}$ produces poorer results for the whole core data and for each facies.

Better results are obtained for regression analysis of $\mathrm{LOI}_{105}$ on $\mathrm{Al}+\mathrm{S}$ for the whole core data $\left(r^{2}=0.907\right.$, Table 9), indicating that $\mathrm{LOI}_{105}$ reflects loss of water of gypsum and clays. However, noticeable changes of $r^{2}$ values among facies reveal the dependence of $\mathrm{LOI}_{105}$ on lithology. 


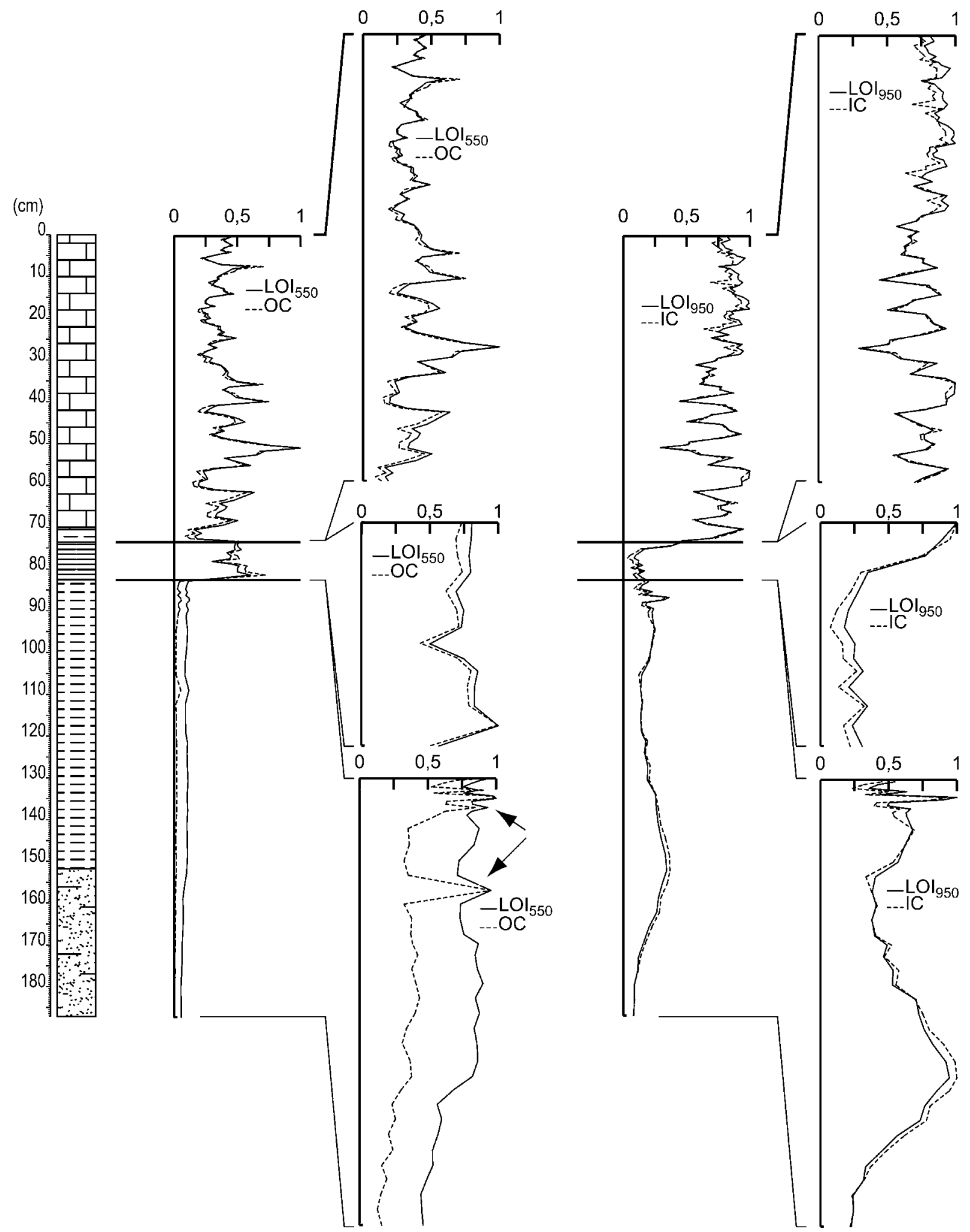

Figure 7. Normalized data for $\mathrm{LOI}_{550}, \mathrm{OC}$ and $\mathrm{LOI}_{950}$, IC calculated for the whole core data and for each facies. Note that two significant peaks on $\mathrm{OC}$ are masked on $\mathrm{LOI}_{550}$ (arrows). 
Table 8. Extreme values and range of variation for the simulation resulting from Dean's $(1974,1999)$ approach and our regression data

\begin{tabular}{|c|c|c|c|c|c|c|}
\hline \multirow[b]{3}{*}{ Dean equations } & \multicolumn{3}{|l|}{$\mathrm{OC}$} & \multicolumn{3}{|l|}{ IC } \\
\hline & \multicolumn{2}{|c|}{ Extreme values (\%) } & \multirow{2}{*}{$\begin{array}{l}\text { Range (\%) } \\
558.66\end{array}$} & \multicolumn{2}{|c|}{ Extreme values (\%) } & \multirow{2}{*}{$\frac{\text { Range }(\%)}{165.3}$} \\
\hline & -534.6 & 24.1 & & -156.8 & 8.6 & \\
\hline Own equation & -171.1 & 167.2 & 338.32 & -151.6 & 13.6 & 165.2 \\
\hline
\end{tabular}

Table 9. Regression coefficients $\left(y=a * \mathrm{LOI}_{105}+b\right)$ for different elements in function of $\mathrm{LOI}_{105}$ (significance level of 0.05)

\begin{tabular}{|c|c|c|c|c|c|c|}
\hline & \multicolumn{2}{|l|}{$\mathrm{Al}$} & \multicolumn{2}{|l|}{$\mathrm{S}$} & \multicolumn{2}{|l|}{$\mathrm{Al}+\mathrm{S}$} \\
\hline & Equation & $r^{2}$ & Equation & $r^{2}$ & Equation & $r^{2}$ \\
\hline Whole core ${ }^{(1)}$ & $a=10.274, b=0.527$ & 0.243 & $a=0.669, b=0.371$ & 0.839 & $a=1.158, b=0.192$ & 0.907 \\
\hline Charophyte layers & $a=0.069, b=0.238$ & 0.037 & $a=0.628, b=0.730$ & 0.615 & $a=0.697, b=0.968$ & 0.615 \\
\hline Organic-rich muds & $a=1.841, b=-1.191$ & 0.600 & $a=0.313, b=-0.180$ & 0.139 & $a=2.153, b=-1.371$ & 0.877 \\
\hline Gypsum-rich muds ${ }^{(1)}$ & $a=-0.411, b=7.879$ & 0.769 & $a=0.989, b=-2.390$ & 0.912 & $a=0.648, b=4.927$ & 0.875 \\
\hline
\end{tabular}

Notice that ${ }^{(1)} 10$ samples are above $10 \%$ of $\mathrm{S}$ (detection limit).

The value of $\mathrm{LOI}_{\text {res }}$ is more difficult to interpret because it includes the residues of all previous ignitions: ashes from combustion of organic matter $\left(\mathrm{LOI}_{550)}\right.$ plus oxides resulting from decomposition of salts $\left(\mathrm{LOI}_{950}\right)$ plus the dewatered clays $\left(\mathrm{LOI}_{105}\right)$. This is corroborated by principal components analysis (Figure 3) which reveals that $\mathrm{LOI}_{\text {res }}$ behaves as an independent factor. Values of $r^{2}$ for regression analysis are not acceptable except for $\mathrm{LOI}_{\text {res }}$ on $\mathrm{Al}$ and on $\mathrm{Ca}$ for the organic-rich mud (Table 10), supporting the hypothesis that it is difficult to assign a reliable interpretation to LOI $_{\text {res }}$ values.

\section{Conclusions}

Analysis of LOI data in a core from the Gigüela River in central Spain yields some conclusions concerning the use of LOI as a substitute method for the measurement of carbon content in sediments. Using data from the whole core, the method provides trends that largely agree with the results of direct measurements. However, the method is unreliable because the composition of sediments induce significant deviations of values. More important, deviations do not follow a predictable trend, which results in the unexpected occurrence or disappearance of peak values. This implies a loss of resolution because, to minimize errors, it would be necessary to use averaged values.
Determinations of organic carbon (OC) are strongly influenced by the content of OC in the sediment: the higher the organic content, the better the correspondence between $\mathrm{OC}$ and $\mathrm{LOI}_{550}$ values obtained via Dean's (1974) approach or regression analysis. Errors arise with very low contents in OC because large and erratic variations have been detected that prohibit any reliable quantitative comparison between facies.

With respect to the inorganic carbon (IC), the results of calculations that use the stoichiometrical relations derived from the transformation: $\mathrm{LOI}_{950} \rightarrow \mathrm{CO}_{2} \rightarrow \mathrm{CO}_{3}{ }^{2-}$ fit very well the IC contents measured directly, but we found major deviations in facies with similar IC contents that still lack explanation. In addition, $\mathrm{LOI}_{950}$ is not a reliable indicator of the total amount of carbonate, because the decomposition of some carbonates begins at temperatures below $550{ }^{\circ} \mathrm{C}$.

In addition, LOI values are influenced by the content in clay (Dean 1974), owing to the very wide range of dehydratation temperatures of clay minerals.

Analysis of relations of variables with $\mathrm{LOI}_{105}$ and $\mathrm{LOI}_{\text {res }}$ suggests that $\mathrm{LOI}_{105}$ is a good qualitative estimate of gypsum. The behaviour of $\mathrm{LOI}_{\text {res }}$ is not easy to interpret, as it does not correlate with the theoretical concept (the remains left after burning). As a general conclusion, LOI cannot be used as an accurate standalone technique for the estimation of carbon content unless the amount of carbon is known and the degree of 
error is estimated. However, LOI is a useful substitute method for analysis of composition of sediments assuming that:

- It yields only qualitative data.

- It requires previous knowledge of the mineralogical composition of sediments.

- The effects of variations in lithology are adequately investigated.

Appropriate techniques of data manipulation are used to avoid the random nature of shifts in values.

\section{Acknowledgements}

We acknowledge financial support from the Spanish Science and Technology Ministry Projects REN2002-04433-CO2-01 and REN2002-04433CO2-02. The staff of Las Tablas de Daimiel National Park kindly gave permissions and technical support in the field. Dr. Mercedes Suárez (University of Salamanca, Spain) kindly carried XRD analyses. We are also in debt to two anonymous reviewers and William M. Last whose corrections have improved the manuscript.

\section{References}

Battarbee R.W., Grytnes J.A., Thompson R., Appleby P.G., Catalan J., Korhola A., Birks H.J.B., Heegaard E. and Lami A. 2002. Comparing palaeolimnological and instrumental evidence of climate change for remote mountain lakes over the last 200 years. J. Paleolim. 28: 161-179.

Beaudoin A. 2003. A comparison of two methods for estimating the organic matter content of sediments. J. Paleolim. 29: 387-390.

Bendell-Young L.I., Thomas Ch.A. and Stecko J.R.P. 2002. Contrasting the geochemistry of oxic sediments across ecosystems: a synthesis. Appl. Geochem. 17: 1563-1582.

Boyle J.F. 2001. Inorganic geochemical methods in palaeolimnology. In: Last W.M. and Smol J.P. (eds), Tracking Environmental Changes Using Lake Sediments, vol. 2, Physical and Geochemical Methods. Developments in Paleoenvironmental Research. Kluwer Academic Publishers, Dordrecht, The Netherlands, pp. 83-141.

Boyle J.F. 2004. A comparison of two methods for estimating the organic matter content of sediments. J. Paleolim. 31: 125127.

Bengtsson L. and Enell M. 1986. Chemical analysis. In: Berglund B.E. (ed.), Handbook of Holocene Palaeoecology and Palaeohydrology. John Wiley \& Sons Ltd, Chichester, pp. 423-451. 
Brauer A., Mingram J., Frank U., Günter Ch., Schettler G., Wulf S., Zolitschka B. and Negendank J.F.W. 2000. Abrupts environmental oscillations during the Early Weichselian recorded at Lago Grande di Monticchio, southern Italy. Quat. Int. 73: (74): 79-90.

Brindley G.W. and LeMaitre J. 1987. Thermal, oxidation and reduction reactions of clay minerals. In: Newman A.C.D. (ed.), Chemistry of Clays and Clay Minerals. Mineralogical Society Monograph, 6. Longman \& Scientific Technical, Essex, pp. 319-370.

Dean W.E. 1974. Determination of carbonate and organic matter in calcareous sediments and sedimentary rocks by loss on ignition: comparison with other methods. J. Sed. Petrol. 44: 242-248.

Dean W.E. 1999. The carbon cycle and biogeochemical dynamics in lake sediments. J. Paleolim. 21: 375-393.

Dodson J.R. and Ramrath A. 2001. An Upper Pliocene lacustrine environmental record from south-Western Australia preliminary results. Palaeogeogr. Palaeoclim. Palaeoecol. 167: 309-320.

Grunsky E.C. 2001. A program for computing RQ-mode principal components analysis for S-PLUS and R. Comp. Geosci. 27: 229-235.

Heiri O., Lotter A.F. and Lemcke G. 2001. Loss on ignition as a method for estimating organic and carbonate content in sediments: reproducibility and comparability of results. J. Paleolim. 25: 101-110.

Ihaka R. and Gentleman R. 1996. R: A language for data analysis and graphics. J. Comp. Graph. Stat. 5: 299314.

Korsman T., Nilsson M.B., Landgren K. and Renberg I. 1999. Spatial variability in surface sediment composition characterisec by near-infrared (NIR) reflectance spectroscopy. J. Paleolim. 21: 61-71.

Lebreton J.D., Sabatier R., Banco G. and Bacou A.M. 1991. Principal component and correspondence analyses with respect to instrumental variables: an overview of their role in studies of structure-activity and species-environment rela- tionships. In: Devillers J. and Karcher W. (eds), Applied Multivariate Analysis in SAR and Environmental Studies. Kluwer Academic Publishers, Dordrecht, The Netherlands, pp. 85-114.

Meyers P.A. and Lallier-Verges E. 1999. Lacustrine sedimentary organic matter records of Late Quaternary paleoclimates. J. Paleolim. 21: 345-372.

Meyers P.A. and Teranes J.L. 2001. Sediment organic matter. In: Last W.M. and Smol J.P. (eds), Tracking Environmental Change Using Lake Sediments. Vol. 2: Physical and Geochemical Methods. Kluwer Academic Publishers, Dordrecht, pp. 239-269.

Ralska-Jasiewiczowa M., Goslar T., Różański K., Wacnik A., Czernik J. and Chróst L. 2003. Very fast environmental changes at the Pleistocene/Holocene boundary, recorded in laminated sediments of Lake Gościąż, Poland. Palaeogeogr. Palaeoclim. Palaeoecol. 193: 225-247.

Ramrath A., Zolitschka B., Wulf S. and Negendank J.F.W. 1999. Late Pleistocene climate variations as recorded in two Italian maar lakes (Lago di Mezzano, Lago Grande di Monticchio). Quat. Sci. Rev. 18: 977-992.

Ran Y., Fu J.M., Sheng G.Y., Beckett R. and Hart B.T. 2000. Fractionation of colloidal and suspended particulate materials in rivers. Chemosphere 41: 33-43.

Rosen M.R., Chagué-Goff C., Eser P. and Coshell L. 2002. Utilisation of the sedimentological and hydrochemical dynamics of the Stump Bay Wetland along Lake Taupo, New Zealand, for the recognition of paleo-shoreline indicators. Sed. Geol. 148: 357-371.

Stecko J.R.P. and Bendell-Young L.I. 2000. Contrasting the geochemistry of suspended particulate matter and deposited sediments within an estuary. Appl. Geochem. 15: 753775.

Valero-Garcés B.L., González-Sampériz P., Delgado-Huertas A., Navas A., Machín J. and Kelts K. 2000. Lateglacial and Late Holocene environmental and vegetational change in Salada Mediana, central Ebro Basin, Spain. Quat. Int. 73: (74): $29-46$ 